\title{
Ichnology of the Devonian (Emsian) Campbellton Formation, New Brunswick, Canada
}

\author{
Olivia A. King ${ }^{1,2}$, Randall F. MilleR ${ }^{1 *}$ And Matthew R. Stimson ${ }^{1}$ \\ 1. Steinhammer Palaeontology Laboratory, Natural Science Department, \\ New Brunswick Museum, Saint John, New Brunswick E2K 1E5, Canada \\ 2. Department of Earth Sciences, Dalhousie University, Halifax, Nova Scotia B3H 4R2, Canada \\ ${ }^{*}$ Corresponding author $<$ randall.miller@nbm-mnb.ca $>$
}

Date received: 20 July 2016 gate accepted: 29 November 2016

\begin{abstract}
The Campbellton Formation has long been known to yield a fossil assemblage of Devonian (Emsian) fish and eurypterids at its westernmost exposure near Campbellton and Atholville, and a well described flora and early land animal fauna toward its easternmost exposure near Dalhousie Junction. Although the body fossil assemblage (paleobotany, vertebrate and invertebrate paleontology), paleoecology and paleoenvironmental context of the formation have been extensively studied, ichnofossils are rare and have not been described previously. Fossils from the vertebrate and eurypterid bearing 'Atholville Beds' contain a low diversity ichnofossil assemblage represented by three ichnotaxa: Monomorphichnus, ?Taenidium and Helminthoidichnites. Monomorphichnus is proposed here as being produced by the produced by the activity of the eurypterid Pterygotus anglicus.
\end{abstract}

\section{RÉSUMÉ}

La formation de Campbellton est depuis longtemps reconnue pour contenir un assemblage de fossiles de poissons et d'euryptéridés du Dévonien (Emsien) sur son affleurement extrême ouest près de Campbellton et d'Atholville, ainsi que pour sa flore et sa faune d'animaux terrestres anciens bien définies vers son affleurement extrême près de Dalhousie Junction. Même si l'assemblage de fossiles corporels (paléobotanique, paléontologie des vertébrés et des invertébrés), la paléoécologie et le contexte paléoenvironnemental de la formation ont été étudiés en profondeur, les ichnofossiles sont rares et ceux présents dans cet assemblage n’ont pas été décrits précédemment. Les fossiles de vertébrés et d'euryptéridés que recèlent les « couches d’Atholville » abritent un assemblage d'ichnofossiles peu diversifié représentés par trois ichnotaxons : le Monomorphichnus, le ?Taenidium et l'Helminthoidichnites. On avance ici que le Monomorphichnus constitue un produit de l'activité de l'euryptéridé Pterygotus anglicus.

[Traduit par la redaction]

\section{INTRODUCTION}

The Devonian (Emsian) Campbellton Formation, exposed along the Restigouche River - Chaleur Bay shoreline in northern New Brunswick, Canada, has been the focus of numerous studies since the late 1800s. Most work has described the flora, which is best preserved toward the eastern exposure of the formation (Kennedy et al.2012a). Many of the described plant-fossil localities occur higher in the Campbellton Formation, cropping out from west of Maple Green to east of Point La Nim (Fig. 1A). The formation is known for its rich flora of zosterophyllophytes, trimerophytes and lycopsids (Gensel and Andrews 1984) and was one of the first sources of Devonian plants to be described in the literature (Dawson 1859). More recently an assemblage of terrestrial arthropods, including Eoarthropleura and disarticulated scorpion cuticle remains (Shear et al. 1996), the millipede Gaspestria genselorum (Wilson 2006), and the eurypterid cf. Parahughmilleria (Miller et al. 2012), attributed to a near-shore lacustrine environment, have been identified from the eastern end of the formation's exposure, near Point La Nim.

Fewer plants, including Psilophyton crenulatum (Doran 1980) and Spongiophyton (Gensel et al. 1991), have been described toward the western exposure of the Campbellton Formation, near Campbellton and Atholville (Fig. 1A, B), 


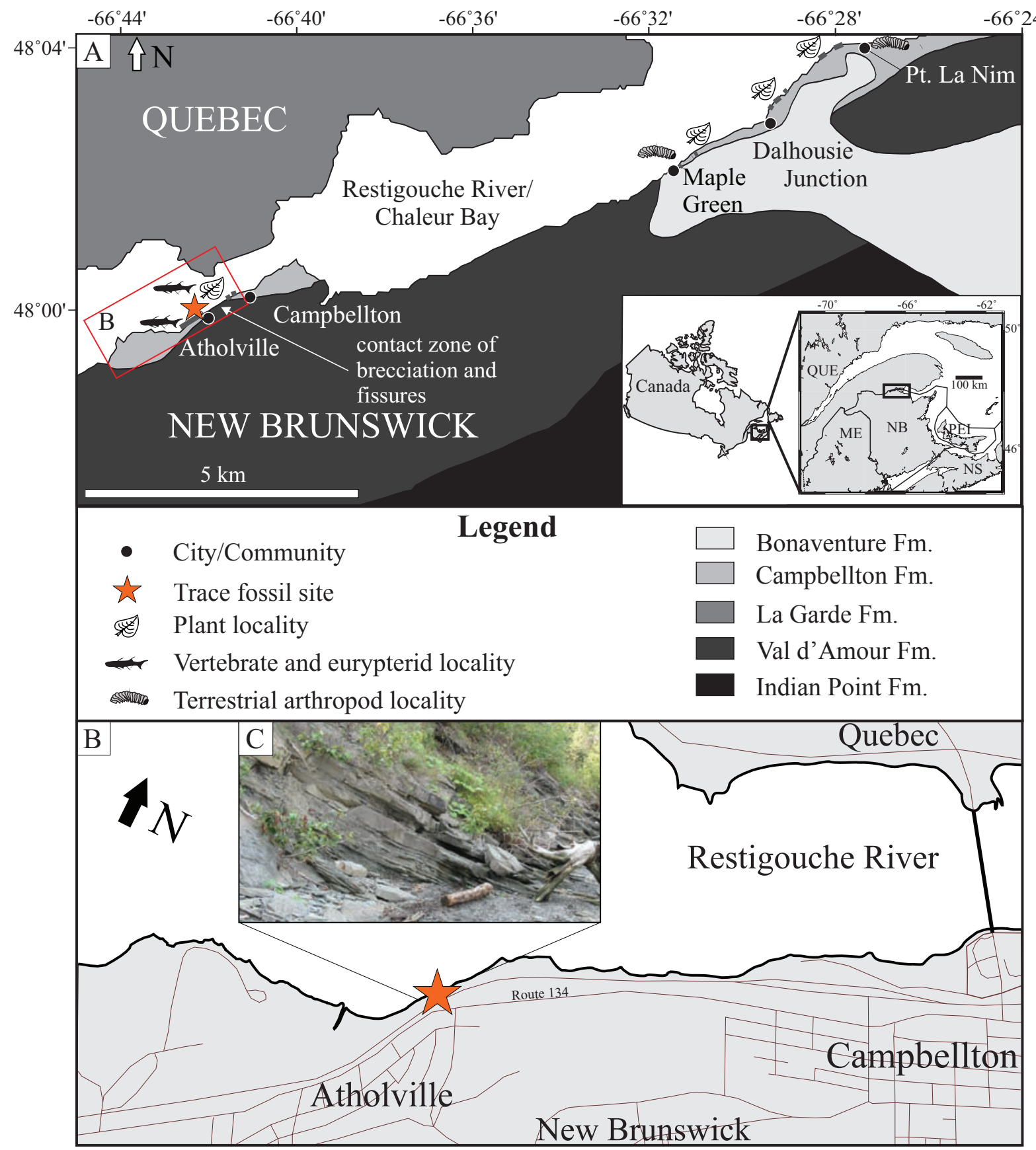

Figure 1. (A) Location map of the Campbellton Formation along the Restigouche River - Chaleur Bay shoreline, New Brunswick. Exposures to the east near Dalhousie Junction contain abundant plants and terrestrial land animals. (B) Exposures to the west, near Campbellton-Atholville, contain fish, pterygotid eurypterids and ichnofossils. (C) Photograph of trace-fossil locality. (Modified after Kennedy et al. 2012b.)

where the base of the formation is in unconformable contact with Val d'Amour Formation rhyolite. The so-called 'Atholville Beds' (Dineley and Williams 1968), exposed at Campbellton and Atholville, have been examined by paleontologists since 1881 and have yielded ostracoderms, arthrodires, acanthodians and chondrichthyans (Whiteaves 1881, 1889; Woodward 1889, 1892; Traquair 1890, 1893). Later detailed descriptions of the fish fauna are based on numerous fossils: acanthodians (Burrow et al. 2008), cephalaspids (Pageau 1969a; Belles-Isles 1989), chondrichthyans (Miller et al. 2003; Turner and Miller 2008) and placoderms (Young 1983), almost all from the breccia-mudstone at the eastern end of the 'Atholville Beds' in Campbellton. In addition to fish, the aquatic assemblage includes eurypterids (Miller 2007a, 2007b), ostracods (Jones 1889) and gastropods (Whiteaves 1881).

The fauna of the Campbellton Formation was summarized by Kennedy et al. (2012b) but, although noted by these 
authors, ichnofossils were not described or assigned to an ichnotaxon. The westernmost Atholville exposure of the formation, where ichnofossils occur, was likely never fully examined by workers prior to the 1990s. A low diversity ichnofossil assemblage discovered in 1995, represented by Monomorphichnus, ?Taenidium and Helminthoidichnites, was recovered from sandstone-siltstone beds that lie above the basal vertebrate-bearing breccia and below the mudstone beds that yielded the numerous eurypterid and fish remains (Fig. 2). The purpose of this paper is twofold: first to document the only ichnofossils known from the Campbellton Formation; and second to propose that specimens of Monomorphichnus from the Campbellton Formation were produced by the feeding behavior of a pterygotid eurypterid.
The ichnofossils Taenidium and Helminthoidichnites are often interpreted as burrows produced by annelids and are typical of delta-front paleoenvironments. The presence of Monomorphichnus is intriguing and will be considered in more detail below. Monomorphichnus has typically been interpreted as having been produced by trilobites, some of the earliest interpretations suggesting that they are grazing traces recording trilobites that made scratch impressions on a channel bed as they were carried along in a current (Crimes 1970; Fillion and Pickerill 1990). Ichnospecies of Monomorphichnus described by Fillion and Pickerill (1990) are also suggestive of active sediment disturbance, rather than passive traces left by an animal moved by currents. We describe traces identified as Monomorphichnus below and speculate on the trace maker and the paleoecological

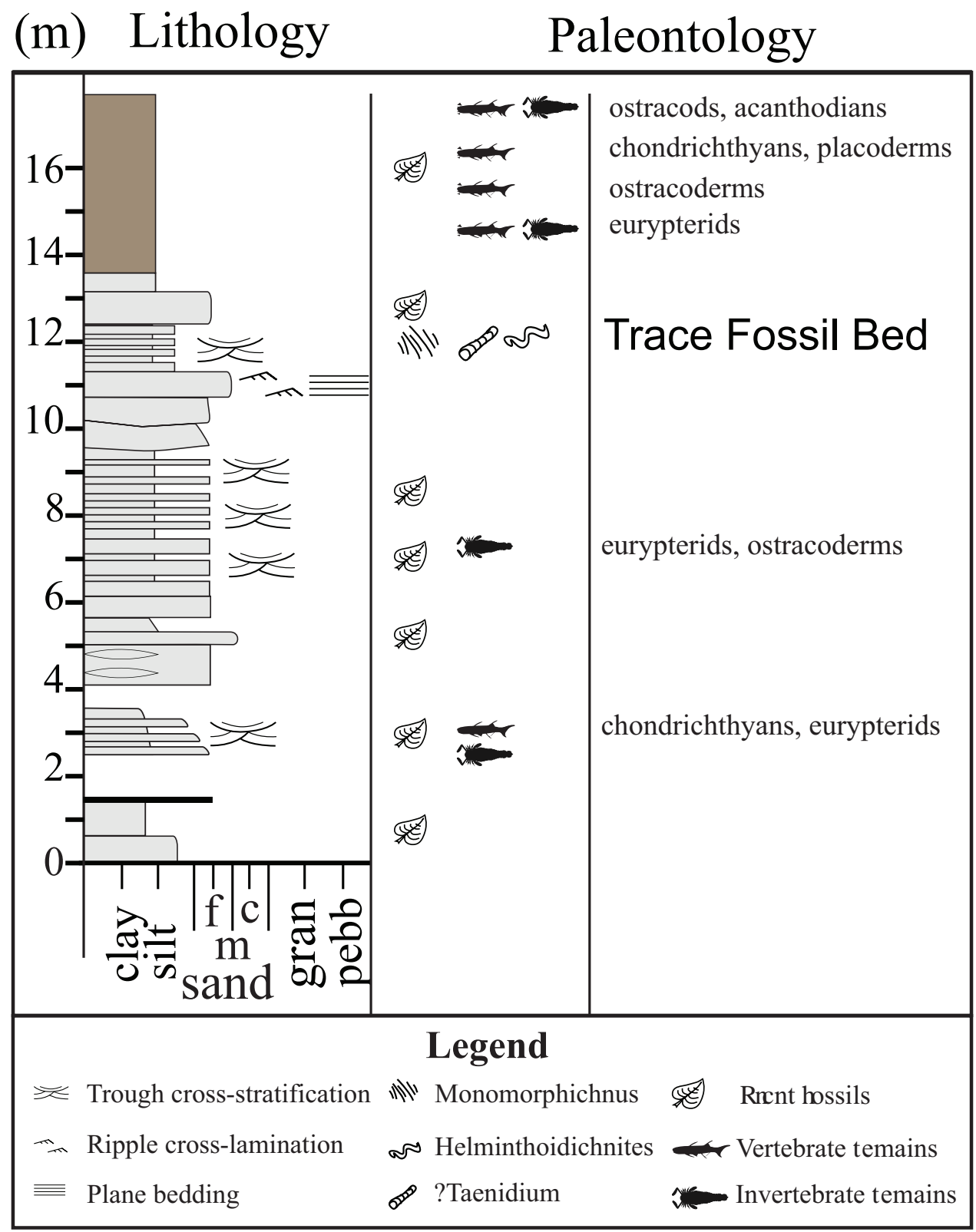

Figure 2. Stratigraphic log of trace-fossil locality, part of the Campbellton Formation. (Modified after Kennedy et al. 2012b.) 
implications. With the exception of rare tasmanitids (prasinophyte algae) that suggest a marine connection (Blieck and Cloutier 2000), no truly marine fossils have been found in the Campbellton Formation.

\section{GEOLOGICAL SETTING}

The Campbellton Formation was defined as largely fluvial in origin, composed of grey volcanic pebble and boulder conglomerate, grey to reddish arkosic sandstone, and dark grey mudstone with local thin coal beds (Williams et al. 1985). These lithologies broadly make up the six main lithofacies described by Kennedy and Gibling (2011) that constitute the fill of this subtropical basin: lacustrine with restricted circulation, marginal lacustrine, near-shore lacustrine, coastal deltaic, braided alluvial plain, and proximal alluvium. The Campbellton Formation is exposed along the banks of the Restigouche River - Chaleur Bay, New Brunswick, in two sections (Wilson et al. 2004; Kennedy and Gibling 2011): one in the west from Atholville to Campbellton; and the other in the east, from near Maple Green to near Dalhousie (Fig. 1A). Between Atholville and Campbellton (Fig. 1B) a discontinuous section is exposed for about $1.5 \mathrm{~km}$. Forest cover and slumping obscures much of the section. Along the shore in this section, the Campbellton Formation overlies rhyolite of the Val d'Amour Formation (Wilson et al. 2004). Kennedy and Gibling (2011) measured a total of about $17 \mathrm{~m}$ of section toward the Atholville end of the exposure (Fig. 2), where steeply inclined strata comprise a basal coarse breccia and a succession of interbedded sandstones and mudstones (Fig. 2).

At Campbellton, the unconformable upper contact with the overlying Carboniferous Bonaventure Formation lies beneath the Restigouche River (Dineley and Williams 1968; Wilson et al. 2004). Some authors (Pageau 1968, 1969a, b) have considered the Campbellton Formation outcrops to be part of either the Battery Point Formation or the LaGarde and Pirate Cove formations (Wilson et al. 2004; Bourque et al. 2005), which are found north of Chaleurs Bay in Gaspé, Quebec. Based on recent palynological data, the Campbellton Formation is of Emsian age (Blieck and Cloutier 2000). The miospores belong to the Emphanisporites annulatus - Camarozonotriletes sextantii Assemblage Zone (Richardson and McGregor 1986), which corresponds approximately to the Polygnathus dehiscens to Polygnathus serotinus conodont zones of early Emsian to early late Emsian age (Blieck and Cloutier 2000). McGregor $(1973,1977)$ considered the outcrops along the Restigouche River to be within the Pragian 'caperatusemsiensis' and early to late Emsian 'sextantii-Grandispora' to 'annulatus-lindlarensis' spore zones. This places the age of these strata between the Pragian-Emsian boundary at $407 \pm 2.8 \mathrm{Ma}$ and the end of Emsian at $397.5 \pm 2.7 \mathrm{Ma}$ (Ogg 2004). Wilson et al. (2004) have provided an alternative age for the Campbellton Formation, suggesting that it straddles the Emsian-Eifelian boundary. Their interpretation is based on a radiometric date of $407.4 \pm 0.8 \mathrm{Ma}$ in the Val d'Amour Formation (Wilson et al. 2004). They recognized an angular unconformity separating the Val d'Amour and Campbellton formations and suggested an age difference of about 10 million years.

Kennedy and Gibling (2011) were the first authors to place the Campbellton Formation into a detailed sedimentological, paleoenvironmental and paleoecological context. Historically, the depositional environment of the Campbellton Formation has been considered fluvial (Dineley and Williams 1968; Williams et al. 1985) or described as a coarsening-upward alluvial-lacustrine sequence (Rust et al. 1989; Gamba 1990; Wilson et al. 2004). Kennedy and Gibling (2011) described strata at the Atholville locality as reflecting a mouthbar-delta front-prodelta setting (Fig. 1C). The horizon containing ichnofossils can be placed within Kennedy and Gibling's 'Section 1, Facies Association 4 Sandy Coastal-deltaic' setting (9 $\mathrm{m}$ above the base of the measured section; Fig. 2; Kennedy et al. 2012b; fig.4), which consists predominately of horizontally bedded sandstone and ripple cross-laminated sandstone, interbedded with lesser massive to laminated siltstone to fine sandstone, massive sandstone, and troughcross-bedded sandstone. Kennedy and Gibling (2011) and Kennedy et al. (2012b) interpreted the association as a sandy deltaic-proximal mouthbar environment with shifting channels and moderate to high energy current flow. Transported terrestrial plant debris is common throughout, with rare articulated and disarticulated aquatic fossils. Ichnofossils occur within a siltstone in a delta-front setting (Fig. 1C, 2).

\section{BIOSTRATIGRAPHY}

Within the mouthbar-delta-front-prodelta setting (Kennedy and Gibling 2011; Kennedy et al. 2012b) three ichnotaxa, Helminthoidichnites, ?Taenidium and Monomorphichnus, have been identified from a single horizon in the delta front sediments. Above the ichnofossil bed is a 2-m-thick mudstone (Fig. 2) attributed to a prodelta setting (Kennedy and Gibling 2011). This unit grades from a dark-grey to black mudstone near its base to a brown mudstone at the top. Near the base of the section plants, ostracods and eurypterids (Miller 1996; Miller 2007a), as well as fish (Kennedy et al. 2012b), are commonly preserved. The upper brown mudstone is devoid of ostracods and has few plant fossils, but has yielded a partially articulated shark (Miller et al. 2003), disarticulated cephalaspids, placoderms and acanthodians, and both articulated and disarticulated eurypterids (Miller 2007a).

The ichnofossil bed lies near the top of $10 \mathrm{~m}$ of interbedded siltstone and sandstone (Kennedy and Gibling 2011; Kennedy et al. 2012b) deposited in alternating mouthbar and delta-front environments (Fig. 2). These rocks have yielded abundant plant detritus, but only rare 
fish and pterygotid remains (Bourque et al. 2005). Ichnotaxa described here were recovered by one of us (RFM) from a siltstone horizon within this sedimentary package (Fig. 1C). These specimens were collected at an undetermined distance above the unconformity with the rhyolites of the Val d'Amour Formation, which have been dated as $407.4 \pm$ $0.8 \mathrm{Ma}$ (Kennedy and Gibling 2011).

\section{METHODOLOGY AND MATERIALS}

Specimens were collected in 1995 and 2012. All specimens were examined in the laboratory, coated in ammonium chloride, and photographed with low raking light to accentuate the vertical relief and morphology of the specimens' surface. Detailed measurements of the traces were taken with a digital caliper for sub-millimeter precision of the width, length and spacing of the scratch traces. Specimens are reposited in the paleontology collection of the New Brunswick Museum, NBMG 2058520588.

\section{SYSTEMATIC ICHNOLOGY}

\section{Ichnogenus Helminthoidichnites Fitch 1850}

Helminthoidichnites tenuis Fitch 1850

(Fig. 3A, 5C)

MATERIAL: NBMG 20585, 20587.

HORIZON AND LOCALITY: Campbellton Formation, Devonian (Emsian), Atholville, New Brunswick $\left(47^{\circ} 59.792^{\prime} \mathrm{N} / 66^{\circ} 42.730^{\prime} \mathrm{W}\right)$.

DIAGNOSIS: Unbranched narrow burrows that are straight to acutely curved, in which individual traces do not cross or intersect. These burrows have a uniform width that can range up to a maximum of $3 \mathrm{~mm}$. (From Hoffman and Mountjoy 2010.)

DESCRIPTION: Sample NBMG 20587 preserves three burrows; and sample NBMG 20585 preserves two burrows that are sub parallel to each other and do not overlap. Both sets of burrows are preserved in light-grey siltstone, vertically flattened to $1.14 \mathrm{~mm}$ high, and infilled with a buff to light-grey, very fine-grained sandstone. Length varies from $28.37 \mathrm{~mm}$ to $59.55 \mathrm{~mm}$, whereas widths vary only slightly around an average of $3.15 \mathrm{~mm}$.

REMARKS: Helminthoidichnites is a tubular trace that can occur at the surface or in the shallow subsurface. The ichnogenus is monospecific and is distinguished from Gordia in that an individual trace does not cross or loop itself. Helminthoidichnites is distinguished from Helminthopsis in that it does not meander.

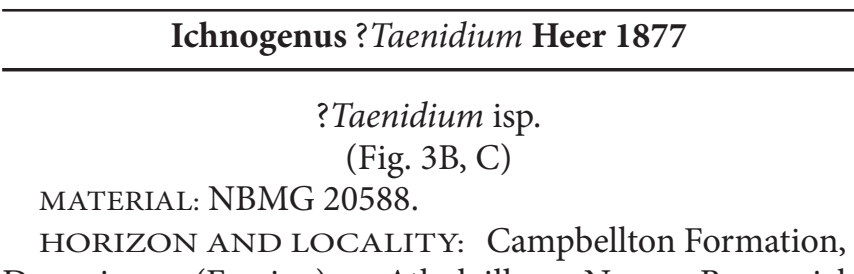

Devonian (Emsian), Atholville, New Brunswick $\left(47^{\circ} 59.792^{\prime} \mathrm{N} / 66^{\circ} 42.730^{\prime} \mathrm{W}\right)$.

DIAGNOSIS: Straight to meandering burrows that are unbranched, unwalled, and backfilled in segments of tightly packed sediment that vary considerably in width. The burrows have sharp boundaries that form non-compartmentalized or thin annulated segments perpendicular to the length of the burrow. The burrows lack a defining lining (Keighley and Pickerill 1994).

DESCRIPTION: Sample NBMG 20588 preserves a simple unbranching cylindrical burrow preserved in convex hyporelief, with a length of $106.9 \mathrm{~mm}$ and width, varying with vertical relief of surface exposure, from $19.4 \mathrm{~mm}$ to $23.9 \mathrm{~mm}$. The burrow is unwalled and exhibits annulated rib-like characteristic features on the surface. This surface texture trends perpendicular to the direction of the burrow. Rib diameter ranges from $2.4 \mathrm{~mm}$ to $2.8 \mathrm{~mm}$, with a spacing that varies between $1.2 \mathrm{~mm}$ and $1.4 \mathrm{~mm}$, and is continuous along the exposed burrow margin.

REMARKS: The taxonomic assignment of this specimen is unclear since the distinguishing feature of menisci-backfill within the burrows is not preserved despite the clear annulations on the outer margin of the trace. According to Keighley and Pickerill (1994), Taenidium is distinguished from Beaconites and Ancorichnus in comprising burrows that are unlined and lack definition around the margin, likely due to active backfilling. The menisci may simply not be preserved internally due to the uniform lithology that infills the burrow and are only preserved as annulations along the burrow's outer margin. Alternatively, the burrow may be uniformly filled, and the regular annulations are a feature of the excavation of the burrow along its margin rather than the result of backfilling. If the latter is the case, it does not conform to the generic concept for Taenidium or any other known ichnotaxon. We questionably assign the trace to Taenidium, as?Taenidium as it most closely resembles this ichnogenus. Because we have only a single example, the preservation of the infill is poor, and the menisci is lacking, we cannot attribute it to a species. 




Figure 3. (A) NBMG 20587, ichnofossil from the Devonian (Emsian) Campbellton Formation, with accompanying close up of Monomorphichnus multilineatus (white arrows), and Helminthoidichites tenuis (black arrows). (B) NBMG 20588, ichnofossil from the Devonian (Emsian) Campbellton Formation featuring ?Taenidium. (C) Close-up of ?Taenidium. (D) NBMG 20586, ichnofossil from the Devonian (Emsian) Campbellton Formation preserving Monomorphichnus multilineatus. 


\section{Ichnogenus Monomorphichnus Crimes 1970}

Monomorphichnus multilineatus Alpert 1976

(Figs. 3A,D, 4A-E, 5A,B, D-I)

MATERIAL: NBMG 20584-20588.

HORIZON AND LOCALITY: Campbellton Formation, Devonian (Emsian), Atholville, New Brunswick $\left(47^{\circ} 59.792^{\prime} \mathrm{N} / 66^{\circ} 42.730^{\prime} \mathrm{W}\right)$.

DIAGNOSIS: A series of straight to sigmoidal ridges with parallel dig traces, the central traces being deeper than the outer traces (after Alpert 1976).

DESCRIPTION: Five specimens with multiple examples of Monomorphichnus multilineatus preserved as convex hyporelief ridges, with the trace ranging from weakly to strongly convex. The traces are composed of a series of straight to sigmoidal ridges. They have an overall elliptical to lensoidal shape, and contain sets of parallel to subparallel ridges interpreted as scratch traces. The individual traces have a minimum length of $15 \mathrm{~mm}$ and a maximum length of $41.9 \mathrm{~mm}$, and widths vary from $13.4 \mathrm{~mm}$ to $32.1 \mathrm{~mm}$. The length to width ratio varies slightly, from 1:1 to 1.4 , such that overall the trace is only slightly longer than wide. Ridges are spaced $1.6 \mathrm{~mm}$ to $2.2 \mathrm{~mm}$ apart with some variability. In rare cases, traces are bilobate with a slightly concave depression between the two sets of ridges. Each set of ridges is generally $8.6 \mathrm{~mm}$ wide and tapers at its termination on both sides (medially and proximally). The ichnofossils vary in depth, and the bedding surfaces on which Monomorphichnus is preserved do not represent the sediment-water interface but rather shallow underprints. No associated traces of legs or body impressions were observed.

REMARKS: First described by Crimes (1970) for traces preserved in the Ffestiniog Stage of the Upper Cambrian from northern Wales, Monomorphichnus has now been described from sedimentary rocks spanning the Cambrian (Crimes 1970; Narbonne and Hofmann 1987) to the Triassic (Shone 1979). Previously Monomorphichnus has been attributed to the trilobite being dragged along the sediment-water interface by currents. Crimes (1970) also suggested that trilobites were grazing as they were dragged along, leaving behind linear drag impressions. Examples of Monomorphichnus were described by Shone (1979), who attributed them to indeterminate arthopods with similar morphological traits to trilobites.

A comprehensive account of the ichnotaxonomy of Monomorphichnus was provided by Fillion and Pickerill (1990). They reviewed the ichnogenus and considered its synonymy with other ichnogenera (Ctenichnites, Eoichnites, Taonichnites and Medusichnites), however they decided to retain Monomorphichnus due to ambiguity as to the whereabouts and status of type specimens of these ichnogenera and given they are widely used ichnotaxon in literature they did not want to introduce confusion and threaten nomenclatural stability. The taxonomic status of
Monomorphichnus is clearly in need of review, but this is beyond the scope of the current manuscript. Fillion and Pickerill (1990) emended Monomorphichnus and included several new ichnospecies; but they still specified that it was made predominantly by trilobites being dragged across the sediment by a current.

\section{DISCUSSION}

Helminthoidichnites, ?Taenidium and Monomorphichnus are preserved within delta-front sediments (Kennedy and Gibling 2011; Kennedy et al. 2012b). Few other faunal remains have been recovered within the delta-front proximal-mouthbar setting of the Campbellton Formation despite over more than 20 years of field visits to the beds yielding ichnofossils. A single chelicera of the eurypterid Pterygotus anglicus (NBMG 10237; Miller 2007a) has been found, as well as partial fin spines tentatively attributed to the shark Doliodus problematicus (NBMG 10237, 12074; see Miller et al. 2003 for a description). A fin spine identified as belonging to the acanthodian Ankylacanthus incurvus (NBMG 11976) (see Burrow et al. 2008 for a description), and partial headshields of Cephalaspis sp. (NBMG 11971, 11972 , 11973) have been previously documented from this locality (Kennedy et al. 2012b). While rare in the delta-front-proximal-mouthbar setting, all of these fossils are relatively abundant several metres up-section in the prodelta setting (Burrow et al. 2008; Miller 1996; Miller 2007a; Miller et al. 2003), suggesting that eurypterids, cephalaspids, chondrichthyans and acathodians may have migrated across paleoenvironments. The traces Taenidium and Helminthoidichnites are usually thought to have been made by annelid worms. Although Monomorphichnus is most often attributed to a trilobite tracemaker, and are frequently preserved in deeper marine environments, the trace has also been described from shallow marine, fluvial and estuarine environments (Fillion and Pickerill 1990). This ichnogenus has been preserved in rocks as young as Permian (Lucas et al. 2005) and Triassic (Shone 1979), where the authors suggested it could have been made by arthropods in non-marine settings, given that trilobites do not extend into non-marine environments or beyond the Permian period. Extensive research has shown that the Campbellton Formation was deposited in a non-marine environment, although distal connections to normal marine environments may have been present (Blieck and Cloutier 2000). The lack of trilobites found in the formation, despite extensive collecting since the 1880 s, is consistent with the paleoenvironmental interpretations of a nonmarine setting, and therefore trilobites are not considered a plausible trace maker for the Monomorphichnus described here.

Jones (2011) described examples of superficially similar traces from the Devonian Catskill Formation of Pennsylvania. These traces were assigned to a new ichnospecies Undichna multilobata; Undichna represents 


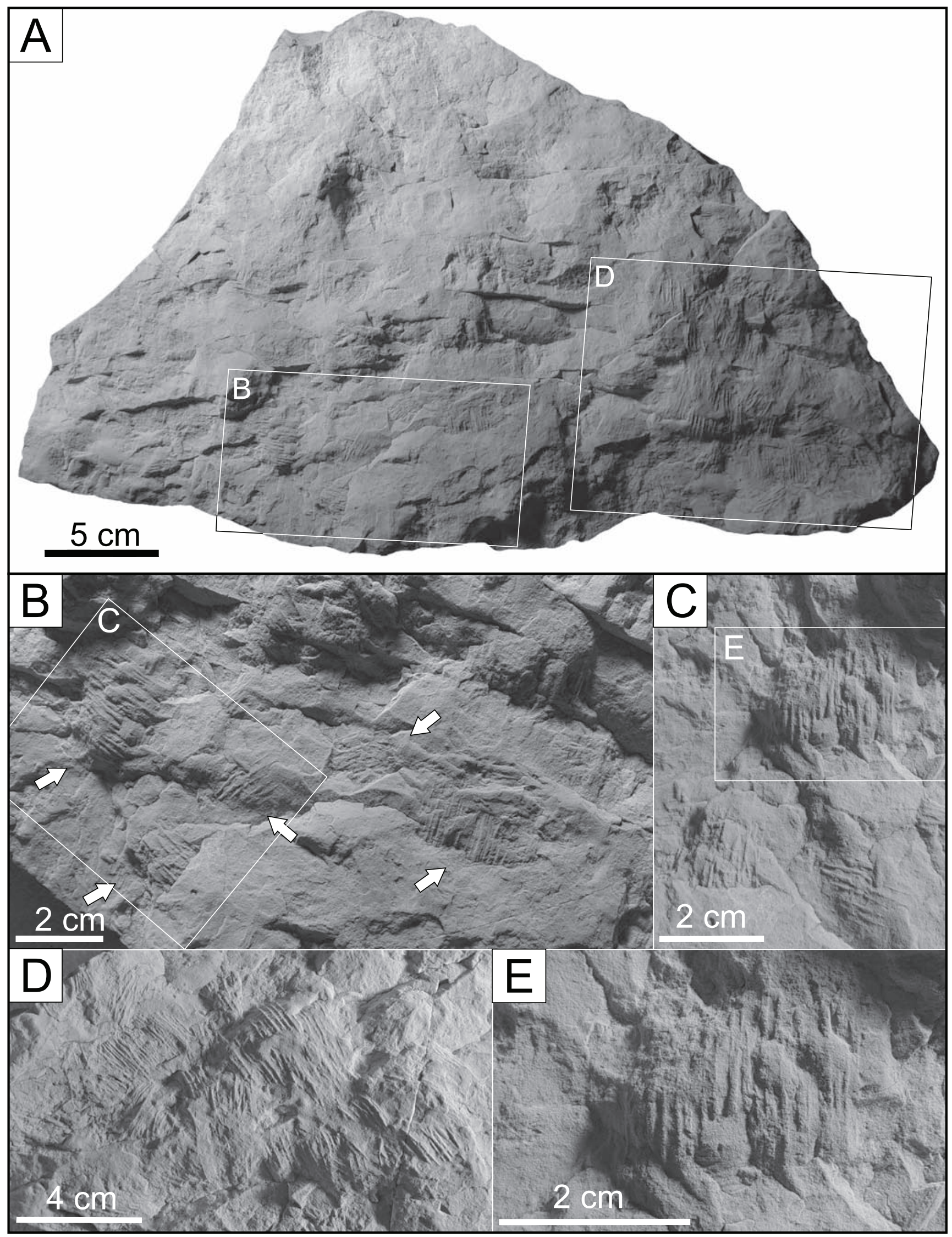

Figure 4. (A) NBMG 20584, ichnofossils from the Devonian (Emsian) Campbellton Formation. (B-E) close-ups of Monomorphichnus multilineatus (white arrows). 


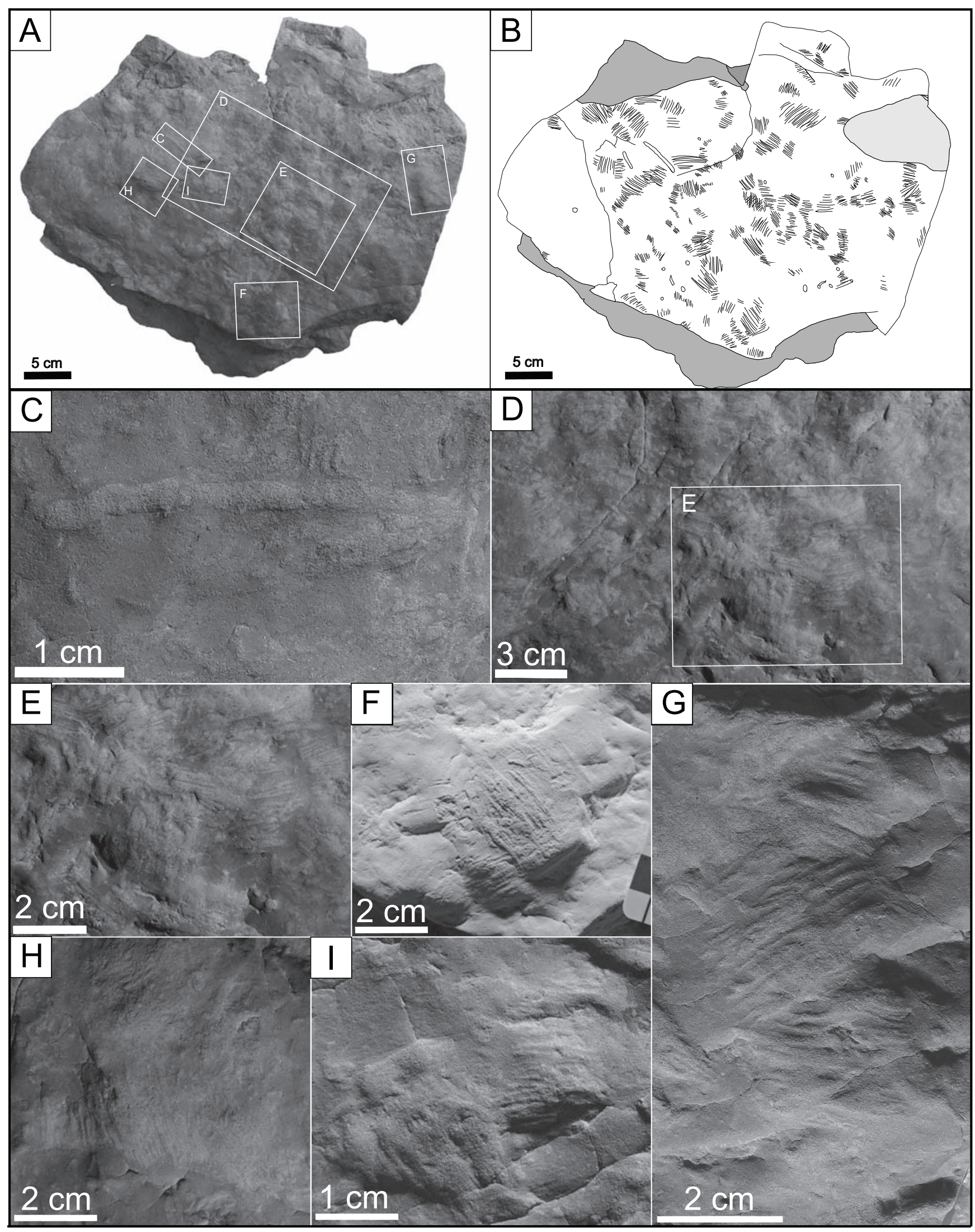

Figure 5. (A) NBMG 20585, ichnofossil from the Devonian (Emsian) Campbellton Formation. (B) Interpretive sketch of NBMG 20585, with Monomorphichnus multilineatus and Helminthoidichnites tenuis. (C) Close-up of Helminthoidichnites tenuis on NBMG 20585. (D-I) Close-ups of Monomorphichnus multilineatus on NBMG 20585. 
fish-fin trails. These traces resemble those described here from the Campbellton Formation. They differ in being composed of 3-5 horizontal paired sets of 'scratch marks' arranged into two linear paths. They were interpreted as the result of placoderm fish dragging or pushing off the sediment. The traces described herein are too irregular in their arrangement to be comparable to those described by Jones (2011).

Vertebrate origins for Monomorphichnus have been considered. The plethora of disarticulated and articulated fish remains (Kennedy et al. 2012b) from the Campbellton site has yielded fin spines with denticles (Burrow et al. 2008; Kennedy et al. 2012b), but these denticles, which could presumably produce parallel scratch impressions, are too small to be a plausible candidate for the Monomorphichnus specimens. Larger spines previously identified as Climatius latispinosus are now attributed the shark Doliodus problematicus (Miller et al. 2003) and not arranged in a way that could be responsible for Monomorphichnus. The well-documented paleoenvironment and inferred salinities of the Campbellton Formation exclude marine animals, and thus trilobites, as possible trace producers, as mentioned above. Although one to one comparisons are rarely possible between ichnofauna and biotaxa, and the possibility of a hitherto unknown trace maker not represented among known body fossils in the Campbellton Formation cannot be fully excluded, we suggest that Monomorphichnus multilineatus as described here is attributed to pterygotid eurypterids. These are currently the only known arthropods, except for ostracods, known from the vertebrate-bearing beds of Campbellton Formation and have morphological features that closely fit the Monomorphichnus traces described here.

In the 'Atholville Beds' of the Campbellton Formation only a single eurypterid species, Pterygotus anglicus, has been identified. This species is among the largest known arthropods, with a body length of two metres or more (Kjellesvig-Waering 1964; Chlupáč 1994). Chelicerae of different sizes have been identified in the Atholville exposure, indicating animals ranging in length from about 65 to $170 \mathrm{~cm}$ (Miller 2007a). Based on our interpretation of trace formation, measurements of Monomorphichnus multilineatus suggest that the animal that made the traces was considerably smaller than the maximum size known for these eurypterids in the Campbellton Formation.

Kjellesvig-Waering (1964) concluded that there was no doubt that most pterygotids were marine, but also lived in nearshore areas such as bays, estuaries and lagoons. He compared them to present-day Xiphosura, which make incursions into brackish waters and up rivers into freshwater environments. Trewin and Davidson (1996) considered that Pterygotus anglicus found in Early Devonian rocks of the Midland Valley of Scotland spent their whole life in fresh water. The Early Devonian fish beds of the Midland Valley are considered lacustrine (Trewin and Davidson 1996; Braddy 2000, 2001), with Pterygotus anglicus at sites such as Tillywhandland sharing 'Lake Forfar' with acanthodians (Mesacanthus, Ischnacanthus and Euthacanthus) and ostracoderms (Cephalaspis pagei). Trewin and Davidson (1996) suggested that since the full size range of Pterygotus anglicus individuals is found in the lake beds, it may have spent its full life cycle in fresh water. A 'mass-moult-mate' hypothesis (Braddy 2001; Vrazo and Braddy 2011) suggested that eurypterids migrated en masse into nearshore and marginal environments such as lagoons to mate and then moult, as they probably required a quiet current-free place. As suggested by these authors, the brackish shoreline environments may have provided a suitable site for moulting, and perhaps account for a range of sizes of individuals from one small locality in the Campbellton Formation (Miller 1996, 2007a). The single Pterygotus anglicus specimen recovered from the delta-front setting supports the idea that the animals also migrated up-river.

Little evidence exists for the diet and feeding strategy of pterygotid eurypterids. However, based on body morphology some are considered to have been active swimmers and top predators, probably feeding on fish (Elliott and Petriello 2011; McCoy et al. 2015; Miller 2007a; Selden 1984). Selden (1984) considered the possible function of pterygotid chelicera, concluding that the animals could rapidly extend these organs during hunting and that the curved tip and multiple denticles of the chelicerae were effective in cutting up prey. Anderson et al. (2014) examined visual acuity in the pterygotid Acutiramus cummingsi and suggested that with its poor vision and cheliceral morphology (see Laub et al. 2010) Acutiramus probably trapped, grasped and sliced weak soft-bodied prey rather than pursuing actively swimming armored prey. Anderson et al. (2014) concluded the ecological role of Acutiramus may have been predation on thin-shelled and soft-bodied prey. McCoy et al. (2015) examined vision in other pterygotids from a small dataset including Jaekelopterus and Pterygotus, the latter including specimen of Pterygotus anglicus (NBMG 10000) from the Campbellton Formation. They concluded that these forms had more robust chelicera and better visual acuity than Acutiramus, and were thus active, visually capable predators. McCoy et al. (2015) also noted that Jaekelopterus vision was less acute in smaller specimens, suggesting vision improved as the animals grew to adults. This might indicate that even if Pterygotus anglicus was an active high-level predator, as a juvenile its vision may have been not as good. Pterygotids as a group probably had diverse feeding strategies. Poschmann et al. (2016) reiterated this idea and, based on visual capability and other body characteristics, considered the stylonurid Rhenopterus diensti as being adapted to crawling on the substrate, feeding on slowmoving soft prey such as worm-like animals, as evidenced by trace fossils found in the same deposits. Poschmann et al. (2016) concluded that the agile pterygotid Jaekelopterus rhenaniae more likely chased active prey.

The morphology of Pterygotus anglicus (Fig. 6A-D) 


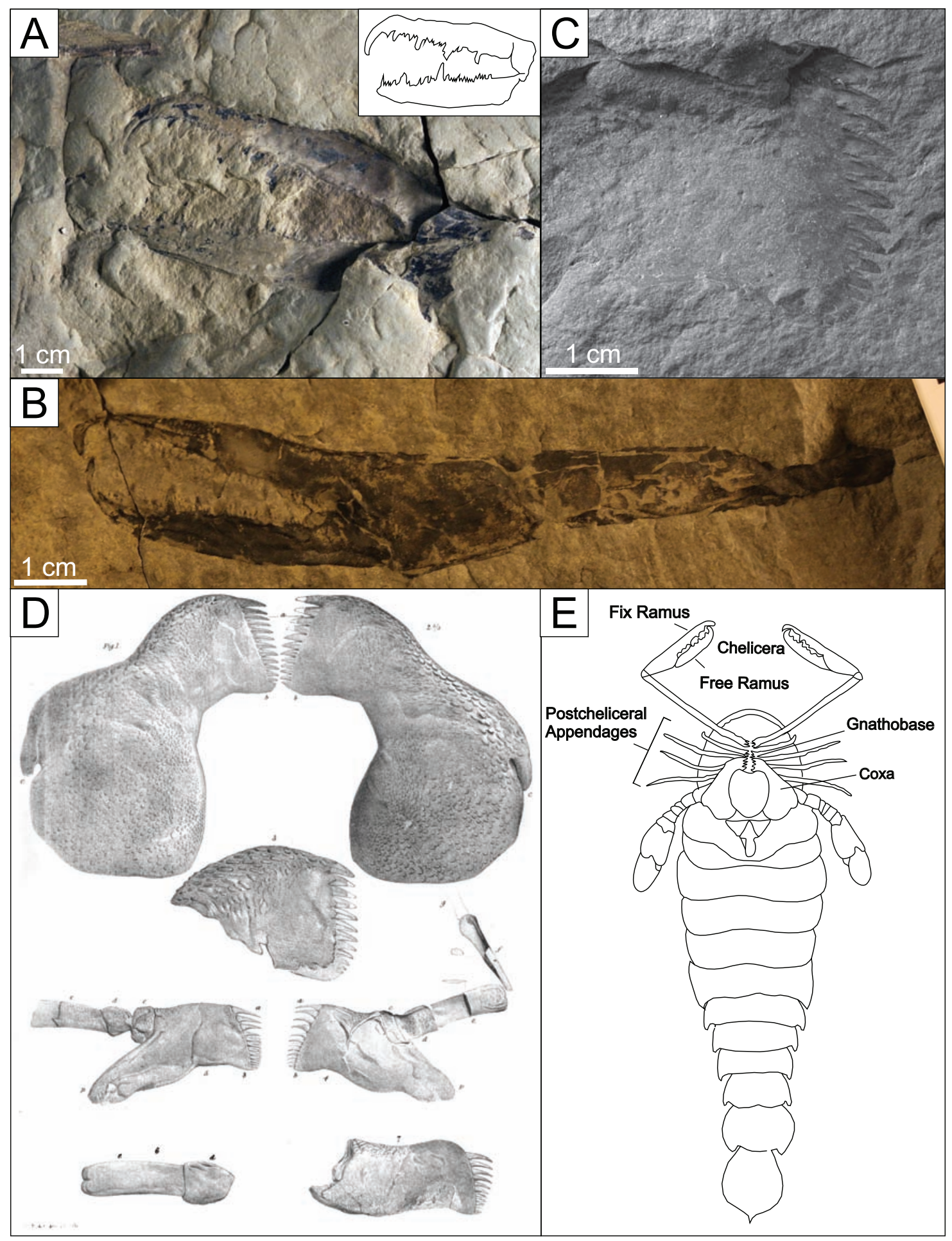

Figure 6. (A) NBMG 10237, a single chelicera of the eurypterid Pterygotus anglicus from delta-front sediments (Kennedy et al. 2012b) of the Campbellton Formation (modified after Miller 2007b; figs. 1, 5). (B) NBMG 15170b a single chelicera of the eurypterid Pterygotus anglicus from prodelta sediments (Kennedy et al. 2012b) of the Campbellton Formation. (C) NBMG 10132, a single gnathobase of coxa of the eurypterid Pterygotus anglicus from the Campbellton Formation, showing 12 denticles (Miller 2007b; fig.11). (D) Interpretive sketch of gnathobase on coxa and walking legs of the eurypterid Pterygotus anglicus (Huxley and Salter 1859; plate XII). (E) Schematic reconstruction of a pterygotid eurypterid, illustrating identifiable structures - chelicera, gnathobase and postcheliceral appendages - possibly responsible for Monomorphichnus (modified after Miller 2007b; fig. 3). The morphology of the postcheliceral appendages 'walking legs' of Pterygotus anglicus is not well-known from the Campbellton Formation specimens, the anterior limb (limb II) here illustrated as a palp after Selden (1986). 
suggests that if the parallel scratch morphology of Monomorphichnus was made by that animal, it most likely resulted from sediment disturbance by either the postcheliceral appendages, the gnathobases (Fig. 6C-D) and coxa (Fig. 6C), or the denticles (Fig. 6A-B) on the fixed and free rami of the chelicera (Huxley and Salter 1859; Clarke and Ruedemann 1912; Miller 2007a). Based on the size and number of striations preserved, we rule out the postcheliceral appendages, which in Pterygotus anglicus are simple and non-spiniferous. Seldon (1986) indicated that the anterior walking leg (limb II) of pterygotid eurypterids was not a slender walking leg, but a small palp, as illustrated by Huxley and Salter (1859). As the first postcheliceral appendage of Pterygotus anglicus is a palp, its purpose being sensation, locomotion, and feeding it could potentially create a trace in the sediment; however the Monomorphichnus traces always occur as a set of multiple, parallel scratches. The gnathobases on the legs of Pterygotus anglicus (Huxley and Salter 1859; Miller 2007a) have 11 to 12 teeth and are located on the proximal end of the appendage (Fig. 6C-D). They are used for carrying or masticating food but, given their position on the body, may not have been used as a scoop to dig in the sediment.

The third possibility is that the chelicerae were used to dig or rake the sediment. Each chelicera has one curved terminal denticle, one primary denticle, and intermediate and smaller denticles in between, for a total of approximately 25 denticles. Raking or sieving the sediment using the chelicerae (Fig. 6A) might be responsible for the Monomorphichnus scratch morphology (Figs. 4, 5). Some arthropods, for example crabs, use a raking or sieving feeding method (Hadlock 1980; Bauchau and PasselecqGérin 1988), including the hermit crab (Pagurus rubricatus) that uses its cheliped to excavate a shallow trench, and uses the chelicerae to transfer sediment and food to the mouth (Schembri 1982). Tshudy and Sorhannus (2000) proposed a raking-and-sieving food-gathering method for fossil decapods that possess chelicerae similar to those of pterygotids. Crayfish exhibit an array of feeding strategies that have been described as opportunistic or generalist, and actively feed on fish similar to the methods used by eurypterids. Crayfish use multiple feeding strategies in addition to active predation including: foraging for benthic invertebrates, and scavenging on deceased vertebrates and invertebrates, or as omnivores feeding on organic plant matter (see Longshaw and Stebbing 2016 and references therein).

These strategies also vary with the seasons and different stages in life cycles. We hypothesize that pterygotid eurypterids may have had a more diverse diet and feeding strategy than only the lie-and-wait predation or active hunting of fish. We speculate that Pterygotus anglicus may have raked the sediment using chelicerae to dislodge annelids responsible for? Taenidium and Helminthoidichnites. This was a foraging strategy used by another eurypterid, Hibbertopterus, which evolved specialized sweep-feeding appendages to rake soft sediment to capture small invertebrates (Jeram and Selden 1993; Selden et al. 2005). Specimens of Monomorphichnus and Helminthoidichnites typically occur together on the same bedding surfaces (Fig. 3A and Fig. 5) and the former may cross-cut the latter (Fig. 3A). We conclude that if Monomorphichus multilineatus described from the Campbellton Formation was produced by Pterygotus anglicus and is found directly associated with ?Taenidium and Helminthoidichnites, Pterygotus anglicus may have had alternate feeding strategies during its life cycle, preying on soft-bodied, slow moving animals.

\section{ACKNOWLEDGEMENTS}

The authors thank J. McGovern and K. Kennedy for assistance and discussion in the field. We thank P. Getty, $\mathrm{V}$. McCoy and an anonymous reviewer for their careful reviews of this manuscript and R. Fensome for his thorough review and edits to the manuscript. We thank S. Lucas, N. Minter and L. Dafoe for useful taxonomic discussions.

\section{REFERENCES}

Alpert, S.P. 1976. Trilobite and star-like trace fossils from the White-Inyo Mountains, California. Journal of Paleontology, 50, pp. 226-239.

Anderson, R.P., McCoy, V.E., McNamara, M.E., and Briggs, D.E. 2014. What big eyes you have: the ecological role of giant pterygotid eurypterids. Biology letters, 10. https://doi.org/10.1098/rsbl.2014.0412

Bauchau, A.G. and Passelecq-Gérin, E. 1988. Adaptive structures to filter-feeding in the sand crab Scopimera gordonae Serene and Moosa, 1981 (Crustacea Decapoda Braçhyura Ocypodidae). Indo-Malayan Zoology, 5, pp. 23-29.

Belles-Isles, M. 1989. Yvonaspis, nouveau genre d'Osteostraci (Vertebrata, Agnatha) du Dévonien (Emsien - Eifélien) des Grès de Gaspé (Québec, Canada). Canadian Journal of Earth Sciences 26, pp. 2396-2401. https:// doi.org/10.1139/e89-204

Blieck, A. and Cloutier, R. 2000. Biostratigraphical correlations of Early Devonian vertebrate assemblages of the Old Red Sandstone Continent. In Palaeozoic vertebrate biochronology and global marine/non-marine correlation. Final Report of IGCP 328 (1991-1996). Edited by A. Blieck and S. Turner. Courier Forschungsinstitut Senckenberg, 223, pp. 223-269

Bourque, P.-A., Desbiens, S., and Gensel, P.G. 2005. Silurian-Devonian biota and paleoenvironments of Gaspé Peninsula and northern New Brunswick. North American Paleontology Conference 2005, Field Guide, NAPC 2005, Halifax, Nova Scotia, 143 p.

Braddy, S.J. 2000. Eurypterids from the Early Devonian of the Midland Valley of Scotland. Scottish Journal of Geology, 36, pp. 115-122. 
Braddy, S.J. 2001. Eurypterid palaeoecology: palaeobiological, ichnological and comparative evidence for a 'mass-moult-mate' hypothesis. Palaeogeography, Palaeoecology, Palaeoclimatology, 172, pp. 115-132. https://doi.org/10.1016/S00310182(01)00274-7

Burrow, C.J., Turner, S., Desbiens, S., and Miller, R.F. 2008. Early Devonian putative gyracanthid acanthodians from eastern Canada. Canadian Journal of Earth Sciences, 45, pp. 897-908. https://doi.org/10.1139/E08-033

Chlupáč, I. 1994. Pterygotid eurypterids (Arthropoda, Chelicerata) in the Silurian and Devonian of Bohemia. Journal of the Czech Geological Society, 39, pp. 147-162.

Clarke, J.M. and Ruedemann, R. 1912. The Eurypterida of New York. Memoirs of the New York State Museum, 14, Vol. 1 and 2, 628 p. https://doi.org/10.5962/bhl. title.66889

Crimes, T.P. 1970. Trilobite tracks and other trace fossils from the Upper Cambrian of North Wales. Geological Journal, 7, pp. 47-68. https://doi.org/10.1002/ gj.3350070104

Dawson, J.W. 1859. On fossil plants from the Devonian rocks of Canada. Quarterly Journal of the Geological Society, London, 15, pp. 477-488. https://doi.org/10.1144/GSL. JGS.1859.015.01-02.57

Dineley, D.L. and Williams, B.P. J. 1968. The Devonian continental rocks of the Lower Restigouche River, Quebec. Canadian Journal of Earth Sciences, 5, pp. 945-953. https://doi.org/10.1139/e68-091

Doran, J.B. 1980. A new species of Psilophyton from the Lower Devonian of northern New Brunswick. Canadian Journal of Botany, 58, pp. 2241-2262. https:// doi.org/10.1139/b80-259

Elliott, D.K. and Petriello, M.A. 2011. New poraspids (Agnatha, Heterostraci) from the Early Devonian of the western United States. Journal of Vertebrate Paleontology, 31, pp. 518-530. https://doi.org/10.1080 /02724634.2011.557113

Fillion, D. and Pickerill, R.K. 1990. Ichnology of the Lower Ordovician Bell Island and Wabana groups of Newfoundland.Palaeontographica Canadiana,7,pp.1-119.

Fitch, A. 1850. A historical, topographical and agricultural survey of the County of Washington. Part 2-5. Transactions of the New York Agricultural Society, 9, pp. 753-944.

Gamba, C.A. 1990. Sedimentological and tectonic implications of the Point la Nim and Campbellton formations, western Chaleur Bay, Maritime Canada. Unpublished M.Sc. thesis, University of Ottawa, Ottawa, Ontario, 249 p.

Gensel, P.G. and Andrews, H.N. 1984. Plant life in the Devonian. Praeger, New York, 380 p.

Gensel, P.G., Chaloner, W.G., and Forbes, W.H. 1991. Spongiophyton from the late Lower Devonian of New Brunswick and Quebec, Canada. Palaeontology, 34, pp. 149-168.
Hadlock, R.P. 1980. Alarm response of the intertidal snail Littorina littorea (L.) to predation by the crab Carcinus maenas (L.). The Biological Bulletin, 159, pp. 269-279. https://doi.org/10.2307/1541092

Heer, O. 1877. Flora fossilis helvetiae. Die vorweltliche Flora der Schweiz. Verlag J. Wurster \& Co., Zurich, parts 3-4 (1877) pp. 91-182.

Hofmann, H.J. and Mountjoy, E.W. 2010. Ediacaran body fossils and trace fossils in Miette Group (Windermere Supergroup) near Salient Mountain, British Columbia, Canada. Canadian Journal of Earth Sciences, 47, pp. 1305-1325.

Huxley, T.H. and Salter, J.W. 1859. On the anatomy and affinities of the genus Pterygotus and description of new species of Pterygotus. Memoirs of the Geological Survey of the United Kingdom, Monograph 1, 105 p.

Jeram A.J. and Selden P.A. 1993. Eurypterids from the Visean of East Kirkton, West Lothian, Scotland. Transactions of the Royal Society of Edinburgh: Earth Sciences, 84, pp. 301-308. https://doi.org/10.1017/S0263593300006118

Jones, T.R. 1889. Notes of the Palaeozoic bivalved Entomostraca No.XXVII. Onsome North American (Canadian) species. Annals and Magazine of Natural History, 6, pp. 373-387. https://doi.org/10.1080/00222938909460354

Jones, W.T. 2011. Ichnotaxonomy and paleoenvironmental analysis of trace fossils in the Late Devonian Catskill Formation, north-central Pennsylvania, USA. Unpublished Ph.D. thesis, University of Kansas, Lawrence, Kansas, 237 p.

Keighley, D.G. and Pickerill, R.K. 1994. The ichnogenus Beaconites and its distinction from Ancorichnus and Taenidium. Palaeontology, 37, pp. 305-338.

Kennedy, K. and Gibling, M.R. 2011. The Campbellton Formation, New Brunswick, Canada: paleoenvironments in an Early Devonian terrestrial locality. Canadian Journal of Earth Sciences, 48, pp. 15611580. https://doi.org/10.1139/e11-055

Kennedy, K., Gensel, P.G., and Gibling, M.R., 2012a. Paleoenvironmental inferences from the classic Lower Devonian plant-bearing locality of the Campbellton Formation, New Brunswick, Canada. Palaios, 27, pp. 424-438. https://doi.org/10.2110/palo.2012.p12-004r

Kennedy, K., Miller, R.F., and Gibling, M.R., $2012 b$. Paleoenvironments of Early Devonian fish and other aquatic fauna of the Campbellton Formation, New Brunswick, Canada. Paleogeography, Paleoclimatology, Paleoecology, 361-362, pp. 61-72. https://doi. org/10.1016/j.palaeo.2012.08.002

Kjellesvig-Waering, E.N. 1964. A synopsis of the family Pterygotidae Clarke and Ruedemann, 1912 (Eurypterida). Journal of Paleontology, 38, pp. 331-361.

Laub, R. S., V. P. Tollerton Jr., and R. S. Berkof. 2010. The cheliceral claw of Acutiramus (Arthropoda: Eurypterida): functional analysis based on morphology and engineering principles. Bulletin of the Buffalo Society of Natural Sciences, 39, pp. 29-42. 
Longshaw, M. and Stebbing, P. 2016. Biology and ecology of crayfish. Taylor and Francis, Boca Raton, Florida, 325 p. https://doi.org/10.1201/b20073

Lucas, S.G., Minter, N.J., Spielmann, J.A., Hunt, A.P., and Braddy, S.J. 2005. Early Permian ichnofossil assemblage from the Fra Cristobal Mountains, southern New Mexico. The Permian of central New Mexico. New Mexico Museum of Natural History and Science Bulletin, 31, pp. 140-150.

McCoy, V.E., Lamsdell, J.C., Poschmann, M., Anderson, R.P., and Briggs, D.E. 2015. All the better to see you with: eyes and claws reveal the evolution of divergent ecological roles in giant pterygotid eurypterids. Biology Letters, 11, 20150564. https://doi.org/10.1098/rsbl.2015.0564

McGregor, D.C. 1973. Lower and Middle Devonian spores of eastern Gaspé, Canada. I. Systematics. Palaeontographica Abteilung B, 142, pp. 1-77.

McGregor, D.C. 1977. Lower and Middle Devonian spores of eastern Gaspé, Canada. II. Biostratigraphic significance. Palaeontographica Abteilung B, 163, pp. 111-142.

Miller, R.F. 1996. Note on Pterygotus anglicus Agassiz (Eurypterida: Devonian) from the Campbellton Formation, New Brunswick. Atlantic Geology, 32, pp. 95-100. https://doi.org/10.4138/2080

Miller, R.F. 2007a. Pterygotus anglicus Agassiz (Chelicerata: Eurypterida) from Atholville, Lower Devonian Campbellton Formation, New Brunswick, Canada. Palaeontology, 50, pp. 981-999. https://doi.org/10.1111/ j.1475-4983.2007.00683.x

Miller, R.F. 2007b. Nineteenth century collections of Pterygotus anglicus Agassiz (Chelicerata; Eurypterida) from the Campbellton Formation, New Brunswick, Canada. Atlantic Geology, 43, pp. 197-209. https://doi. org/10.4138/5649

Miller, R.F., Cloutier, R., and Turner, S. 2003. The oldest chondrichthyan from the Early Devonian period. Nature, 425, pp. 501-504. https://doi.org/10.1038/nature02001

Miller, R.F., Kennedy, K., and Gibling, M.R. 2012. A eurypterid from the lacustrine facies of the Early Devonian Campbellton Formation, New Brunswick, Canada. Atlantic Geology, 48, pp. 14-19. https://doi. org/10.4138/atlgeol.2012.002

Narbonne, G.M. and Hofmann, H.J. 1987. Ediacaran biota of the Wernecke Mountains, Yukon, Canada. Palaeontology, 30, pp. 647-676.

Ogg, J.G. 2004. Status of divisions of the International Geologic Time Scale. Lethaia, 37, pp. 183-199. https:// doi.org/10.1080/00241160410006492

Pageau, Y. 1968. Nouvelle faune ichthyologique du Dévonien moyen dans les Grès de Gaspé (Québec). I. Géologie et écologie. Naturaliste Canadien, 95, pp. 1459-1497.

Pageau, Y. 1969a. Nouvelle faune ichthyologique du Dévonien moyen dans les Grès de Gaspé (Québec). II. Morphologie et systématique. Première section: A. Euryptérides, B. Ostracodermes, C. Acanthodiens et Sélaciens. Naturaliste Canadien, 96, pp. 399-478.
Pageau, Y. 1969b. Nouvelle faune ichthyologique du Dévonien moyen dans les grès de Gaspé (Québec). II. Morphologie et systématique. Deuxième section: Arthrodires: Dolicothoraci. Naturaliste Canadien, 96, pp. 805-889.

Poschmann, M., Schoenemann, B., and McCoy, V.E. 2016. Telltale eyes: the lateral visual systems of Rhenish Lower Devonian eurypterids (Arthropoda, Chelicerata) and their palaeobiological implications. Palaeontology, 59, pp. 295-304. https://doi.org/10.1111/pala. 12228

Richardson, J.B. and McGregor, D.C. 1986. Silurian and Devonian spore zones of the Old Red Sandstone continent and adjacent regions. Geological Survey of Canada, Bulletin, 364, 79 p. https://doi. org/10.4095/120614

Rust, B. R., Lawrence, D.A., and Zaitlin, B.A. 1989. The sedimentology and tectonic significance of Devonian and Carboniferous terrestrial successions in Gaspé, Quebec. Atlantic Geology, 25, pp. 1-13. https://doi. org/10.4138/1666

Schembri, P.J. 1982. Functional morphology of the mouthparts and associated structures of Pagurus rubricatus (Crustacea: Decapoda: Anomura) with special reference to feeding and grooming. Zoomorphology, 101, pp. 17-38. https://doi.org/10.1007/BF003 12028

Selden, P.A. 1984. Autecology of Silurian eurypterids, pp. 39-54. In Autecology of Silurian organisms (Vol. 32). Edited by M.G. Bassett and J.D. Lawson, J. D. Special Papers in Palaeontology, 32, Palaeontological Association, London, 295 p.

Seldon, P.A. 1986. A new identity for the Silurian arthropod Necrogammarus. Palaeontology, 29, pp. 629-631.

Selden, P.A., Corronca, J.A., and Hünicken, M.A. 2005. The true identity of the supposed giant fossil spider Megarachne. Biology Letters, 1, pp. 44-48.

Shear, W., Gensel, P., and Jeram, A. 1996. Fossils of large terrestrial arthropods from the Lower Devonian of Canada. Nature, 384, pp. 555-557. https://doi. org $/ 10.1038 / 384555 \mathrm{a} 0$

Shone, R.W. 1979. Giant Cruziana from the Beaufort Group. Geological Society of South Africa Transactions, 82, pp. 371-375.

Traquair, R.H. 1890. Notes on the Devonian fishes of Scaumenac Bay and Campbelltown in Canada. Geological Magazine, 7, pp. 15-22. https://doi. org/10.1017/S0016756800146126

Traquair, R.H. 1893. Notes on the Devonian fishes of Campbelltown and Scaumenac Bay in Canada-No. 2. Geological Magazine, 10, pp. 145-149. https://doi. org/10.1017/S0016756800170232

Trewin, N.H. and Davidson, R.G. 1996. An Early Devonian lake and its associated biota in the Midland Valley of Scotland. Transactions of the Royal Society of Edinburgh: Earth Sciences, 86, pp. 233-246. https:// doi.org/10.1017/S0263593300007641 
Tshudy, D. and Sorhannus, U. 2000. Pectinate claws in decapod crustaceans: convergence in four lineages. Journal of Paleontology, 74, pp. 474-486. https://doi. org/10.1017/s0022336000031735

Turner, S. and Miller, R.F. 2008. Protodus jexi Woodward, 1892 (Chondrichthyes), from the Lower Devonian Campbellton Formation, New Brunswick, Canada. Acta Geologica Polonica, 58, pp. 133-145.

Vrazo, M.B. and Braddy, S.J. 2011. Testing the 'massmoult-mate' hypothesis of eurypterid palaeoecology. Palaeogeography, Palaeoclimatology, Palaeoecology, 311, pp. 63-73. https://doi.org/10.1016/j.palaeo.2011.07.031

Whiteaves, J.F. 1881. On some fossil fishes, Crustacea and Mollusca from the Devonian rocks at Campbellton, N.B., with description of five new species. Canadian Naturalist and Quarterly Journal of Science, 10, pp. 93-101.

Whiteaves, J.F. 1889. Illustrations of the fossil fishes of the Devonian rocks of Canada, part II. Transactions of the Royal Society of Canada, 6, pp. 77-96.

Williams, G.L., Fyffe, L.R., Wardle, R.J., Colman-Sadd, S.P., and Boehner, R.C. 1985. Lexicon of Canadian stratigraphy, Volume VI, Atlantic region. Canadian Society of Petroleum Geologists, Calgary, 572 p.
Wilson, H.M. 2006. Juliformian millipedes from the Lower Devonian of Euramerica: implications for the timing of millipede cladogenesis in the Paleozoic. Journal of Paleontology, 80, pp. 638-649. https://doi. org/10.1666/0022-3360(2006)80[638:JMFTLD]2.0. $\mathrm{CO} ; 2$

Wilson, R.A., Burden, E.T., Bertrand, R., Asselin, E., and McCracken, A.D. 2004. Stratigraphy and tectonosedimentary evolution of the Late Ordovician to Middle Devonian Gaspé Belt in northern New Brunswick: evidence from the Restigouche area. Canadian Journal of Earth Sciences, 41, pp. 527-551. https://doi.org/10.1139/e04-011

Woodward, A.S. 1889. Acanthodian fishes from the Devonian of Canada. Annals and Magazine of Natural History, 4, pp. 183-184. https://doi. org/10.1080/00222938909460500

Woodward, A.S. 1892. On the Lower Devonian fish-fauna of Campbellton, New Brunswick. Geological Magazine, 9, pp. 1-6. https://doi.org/10.1017/S0016756800188533

Young, V.T. 1983. Taxonomy of the arthrodire Phlyctaenius from the Lower or Middle Devonian of Campbellton, New Brunswick, Canada. Bulletin of the British Museum of Natural History 371, pp. 1-35.

Editorial responsibility: Robert A. Fensome 